\title{
FISCAL DECENTRALIZATION AND ECONOMIC GROWTH IN SELECTED EUROPEAN COUNTRIES
}

\author{
Neringa SLAVINSKAITE் \\ Department of Enterprise Economic and Management, Faculty of Business Management, \\ Vilnius Gediminas Technical University, Sauletekio al. 11, LT-10223, Vilnius, Lithuania \\ E-mail: neringa.slavinskaite@gmail.com
}

Received 07 November 2016; accepted 18 December 2016

\begin{abstract}
The paper analyses the fiscal decentralization effects on economic growth in unitary countries of European Union for the period 2005-2014. The empirical analysis was based on the multiple regression method. The fixed effect panel model was used as framework for the analysis. In order to examine the different impact of fiscal decentralization, the same analysis was applied to subsets of countries categorized into two groups according to countries' level of economic development. This further analysis found that there is positive relationship between fiscal decentralization and economic growth in low level of economically developing countries and no relationship in high level of economically developed countries. These results suggested that fiscal decentralization is not always instrument for promotion of economic growth, which means that country's economic development level is an important factor when introducing reform of fiscal decentralization. The originality of this article - new fiscal decentralization index and evaluated fiscal decentralization level influence for countries economic growth.
\end{abstract}

Keywords: EU countries, index of fiscal decentralization, growth of economic, panel data, fixed effect panel model, local government.

JEL Classification: E62, H71, H72.

\section{Introduction}

The decentralization of public services and their financing is high on the economic agenda and has triggered a growing interest in measurement issues. Fiscal decentralization has become an interesting topic until today because researches about fiscal decentralization (FD) are not only discussed from the economic perspective, but also from other perspectives such as politic, geographic, other subjects. Appropriate indicators can help governments compare, diagnose and reform intergovernmental fiscal frameworks as well as assess the outcome of past reforms. They can help assess whether and to what extent decentralization fosters economic growth (EG), raises the efficiency of the public sector or contributes to macroeconomic stability. The issue has attracted the attention of both academics and international institutions such as OECD and World Bank. 
In the scientific world, the question of how fiscal decentralization effects economic growth of country has been analysed by many scientists (Oates 1999; Akai, Sakata 2002; Thiessen 2003; Iimi 2005; Buser 2011; Szarowska 2014). The arguments for the positive influence of fiscal decentralization consist of 3 different hypothesis: 1) the diversification hypothesis (also known as the decentralization theorem); 2) the Levethan hypothesis; 3) the productivity enhancement hypothesis.

Briefly summarized, the central argument of fiscal federalism is that the efficiency and adequacy of locally provided public services are ensured through citizen mobility, voting power and competition among local governments in adequate ecosystem creation (Wahl, Prause 2013; Tunčikienè, Drejeris 2015; Fuschi, Tvaronavičienė 2016).

The purpose of this article - to evaluate fiscal decentralization impact on economic growth in selected unitary European countries in a period 2005-2014.

\section{The following goals have been set to achieve stated object:}

- to review the scientific literature of fiscal decentralization;

- to evaluate with fixed effect model (FEM) how level of fiscal decentralization effects economic growth in unitary Europe Union countries.

Research methods: graphical analysis, grouping, summing up, regression analysis. This paper has three parts: 1) literature review 2) empirical methodology 3) regression results. Conclusions are in the last section.

\section{Literature review of fiscal decentralization and economic growth}

Economic growth is affected by wide arrow of factors (Travkina, Tvaronavičienè 2015; Ignatavičius et al. 2015; Aleksejeva 2016; Genys 2016), among which fiscal decentralization plays certain role (Musgrave 1959; Oates 1972). What is the relationship between FD and economic growth? According to the fiscal federalism theory (Tiebout 1956; Oates 1972), local government fiscal autonomy ensures efficient allocative outcome, which may eventually lead to higher rates of growth.

The first theoretical discussion of fiscal decentralization from economic point of view dates back to the middle of the twentieth century. Musgrave (1959) and Tiebout (1956) formulated the theoretical foundations of fiscal federalism. These ideas were further developed by Oates $(1972,1993,1999)$ and Brennan, Buchanan (1980).

Traditionally, the economic aspect of decentralization was analysed through the framework of fiscal federalism. At this point, it is important to distinquish differences between concepts of fiscal decentralization and fiscal federalism. While fiscal federalism is a framework for analysis of nation's public sector, decentralization is a process of public sector activities assignment to government different levels. Thus, fiscal federalism is the system of reference within which the process of decentralization or centralization occurs.

The results of numerous researches on the relationship between FD and economic growth, both from a cross-country and regional perspective, are very contradictory. 
There is no one answer to this question. Some researches find a positive relationship (Akai, Sakata 2002; Akai et al. 2004; Thiessen 2003; Iimi 2005; Buser 2011; Szarowska 2014), whereas other show that FD and economic growth are either negatively correlated (Davoodi, Zou 1998; Rodríguez-Pose, Ezcurra 2011; Baskaran, Feld 2013). There is a group of researchers who have found relation between FD and economic growth, but it is no statistically significant (Davoodi, Zou 1998; Thornton 2007; Asatryan, Feld 2015). In Table 1, summarized empirical findings of researches on the impact of FD on economic growth in cross - countries, are presented:

Table 1. Empirical findings in cross-countries terms

\begin{tabular}{|c|c|c|c|c|}
\hline Authors & Year & $\begin{array}{l}\text { Time period, } \\
\text { sample }\end{array}$ & Method & Main results \\
\hline Thiessen & 2003 & $\begin{array}{l}1973-1998 \\
\text { OECD } \\
\text { countries }\end{array}$ & OLS & $\begin{array}{l}\text { FD by } 10 \% \text { increases EG by } 0.15 \% \\
\text { points }\end{array}$ \\
\hline Eller & 2004 & $\begin{array}{l}1972-1996 \\
22 \text { OECD } \\
\text { Countries }\end{array}$ & Fixed Effects & $\begin{array}{l}\text { There is a positive effect of FD on } \\
\text { EG }\end{array}$ \\
\hline Iimi & 2005 & $\begin{array}{l}1997-2001 \\
51 \text { countries }\end{array}$ & OLS & $\begin{array}{l}\text { FD by } 10 \% \text { increases EG by } \\
0.6 \% \text { points }\end{array}$ \\
\hline Thornton & 2007 & $\begin{array}{l}1980-2000 \\
19 \text { OECD } \\
\text { countries }\end{array}$ & OLS & Negative effect of FD on EG \\
\hline $\begin{array}{l}\text { Rodríguez- } \\
\text { Pose, Kroijer }\end{array}$ & 2009 & $\begin{array}{l}\text { 1990-2004 } \\
\text { Countries of } \\
\text { Central and } \\
\text { Eastern Europe }\end{array}$ & Fixed Effects & Negative effect of FD on EG \\
\hline $\begin{array}{l}\text { Rodríguez- } \\
\text { Pose, } \\
\text { Ezcurra }\end{array}$ & 2011 & $\begin{array}{l}1990-2005 \\
21 \text { OECD } \\
\text { countries }\end{array}$ & OLS & Negative effect of FD on EG \\
\hline $\begin{array}{l}\text { Gemmell } \\
\text { et al. }\end{array}$ & 2013 & $\begin{array}{l}1972-2005 \\
23 \text { OECD } \\
\text { countries }\end{array}$ & $\begin{array}{l}\text { Pooled Mean } \\
\text { Group }\end{array}$ & $\begin{array}{l}\text { FD decreases EG, revenue } \\
\text { decentralization increases EG }\end{array}$ \\
\hline $\begin{array}{l}\text { Baskaran, } \\
\text { Feld }\end{array}$ & 2013 & $\begin{array}{l}1975-2008 \\
23 \text { OECD } \\
\text { countries }\end{array}$ & Fixed Effects & Negative effect of FD on EG \\
\hline Szarowska & 2014 & $\begin{array}{l}1995-2012 \\
17 \text { unitary } \\
\text { Europe } \\
\text { countries }\end{array}$ & $\begin{array}{l}\text { Generalized } \\
\text { Method of } \\
\text { Moments }\end{array}$ & Positive effect of FD on EG \\
\hline $\begin{array}{l}\text { Abdellati } \\
\text { et al. }\end{array}$ & 2015 & $\begin{array}{l}2002-2008 \\
18 \text { East European } \\
\text { countries }\end{array}$ & $\begin{array}{l}\text { Generalized } \\
\text { method of } \\
\text { moments }\end{array}$ & FD has a positive impact on EG \\
\hline
\end{tabular}

Source: compiled by author. 
The most widely used cases in the regional studies are obviously Chinese provinces and American states, because both countries offer sufficient samples (50 American states and 28 Chinese provinces) substantial heterogeneity among region in terms of economic and fiscal performance and reliable statistical data for a long period of time. Nevertheless, there is no consensus on the direction and significance of this relationship (Zhang, Zou 1998; Lin, Liu 2000; Jin, Zou 2005; Akai et al. 2009). In Table 2, summarized empirical findings of studies on the influence of FD or federalism on economic growth in the Chinese, Spanish and USA, are presented.

Table 2. Empirical findings in terms of federative countries

\begin{tabular}{|c|c|c|c|c|}
\hline Authors & Year & Time period, sample & Method & Main results \\
\hline Stansel & 2005 & $\begin{array}{l}1960-1990 \\
314 \text { US Metropolitan } \\
\text { areas }\end{array}$ & Robust OLS & $\begin{array}{l}\text { FD has a positive impact on } \\
\text { EG }\end{array}$ \\
\hline Akai et al. & 2009 & $\begin{array}{l}1992-1997 \\
50 \text { US States }\end{array}$ & $\begin{array}{l}\text { Maximum } \\
\text { Likelihood }\end{array}$ & $\begin{array}{l}\text { Positive relationship between } \\
\text { FD and EG }\end{array}$ \\
\hline $\begin{array}{l}\text { Cantarero, } \\
\text { Gonzalez }\end{array}$ & 2009 & $\begin{array}{l}\text { 1985-2004 } \\
\text { Spanish regions }\end{array}$ & $\begin{array}{l}\text { GLS and fixed } \\
\text { effect }\end{array}$ & $\begin{array}{l}\text { There is not statistically } \\
\text { significant linkage between } \\
\text { FD and EG }\end{array}$ \\
\hline $\begin{array}{l}\text { Hammond, } \\
\text { Tosun }\end{array}$ & 2011 & $\begin{array}{l}\text { 1970-2000 } \\
\text { USA Metropolitan and } \\
\text { no metropolitan areas }\end{array}$ & $\begin{array}{l}\text { Fixed effect, } \\
\text { lag }\end{array}$ & $\begin{array}{l}\text { Negative and positive effect of } \\
\text { FD on EG }\end{array}$ \\
\hline Chu, Zheng & 2013 & $\begin{array}{l}\text { 1996-2005 } \\
\text { 31 Chinese provinces }\end{array}$ & $\begin{array}{l}\text { Two-stage least } \\
\text { squares }\end{array}$ & $\begin{array}{l}\text { FD has a positive impact on } \\
\text { EG }\end{array}$ \\
\hline Jalil et al. & 2014 & $\begin{array}{l}\text { 1979-2009 } \\
\text { China's provinces }\end{array}$ & $\begin{array}{l}\text { ARDL, bounds } \\
\text { tests, pooled } \\
\text { mean group } \\
\text { estimators }\end{array}$ & $\begin{array}{l}\text { There is positive and } \\
\text { statistically significant linkage } \\
\text { between FD and EG }\end{array}$ \\
\hline Yang & 2016 & $\begin{array}{l}1990-2012 \\
29 \text { Chinese provinces }\end{array}$ & Fixed effect & $\begin{array}{l}\text { Positive relationship between } \\
\text { FD and EG }\end{array}$ \\
\hline
\end{tabular}

Source: compiled by author.

Some empirical studies (Davoodi, Zou 1998) found that FD effects are different in developed and developing countries: FD has negative correlation on economic growth in developing countries, but FD and economic growth has no significance relation in developed countries.

\section{Data and methodology}

The main purpose of the paper was to analyse the effect of FD on economic growth in unitary European Countries for the period 2005-2014 (data available was till 2014). Luxembourg and Malta have not been included, because economic growth of Luxembourg is bigger than other EU countries, fiscal decentralization level of Malta is very low. This empirical analysis was based on the multiple regression - Fixed effect model. 
In order to examine the different impact of fiscal decentralization, the same analysis was applied to subsets of countries categorized into two groups according to the economical development stage of countries by GDP per capital:

- a high level of economic development countries: Denmark (DK), Finland (FI), France (FR), Ireland (IR), Italy (IT), Netherlands (NL), Sweden (SW) and United Kingdom (UK);

- a low level of economic development countries: Bulgaria (BG), Croatia (HR), Cyprus (CY), Czech Respublic (CZ), Estonia (ES), Hungary (HU), Latvia (LV), Lithuania (LT), Poland (PO), Portugal (PT), Slovak Respublic (SK), Slovenia (SV), Rumunia (RO).

The data for the analysis was taken from OECD Fiscal decentralization Database (OECD 2016), Word Bank (2016), Eurostat (2016). Fiscal decentralization has many indicators: expenditure decentralization, revenue decentralization, borrow power and intergorvernmental transfer. In this paper fiscal decentralization index (FDI) as fiscal decentralization variable was used (see Slavinskaité, Ginevičius 2016).

Reseachers have modified popular economic growth models (Solow model, Bario's endogenous growth model and Diamond's overlapping generations model) to intercorporate a potential reliationship between fiscal decentralization and economic growth (Davoodi, Zou 1998; Akai et al. 2004; Nguyen, Anwar 2011; Baskaran, Feld 2013; Yushkov 2015; Filippetti, Sacchi 2016). The most common analytical framework that links expenditure decentralization to growth is a model developed by Davoodi and Zou (1998), which is a modified version of Bario's model (Barro 1990), where economic growth is a function of multiple inputs including private capital, human capital and multiple public spending. Growth endogenous Bario (1990) model has examined the aggregate government spending, (where both aggregate public consumption and aggregate public investment were included) and an effect on economic growth of country.

The model adopts the following form:

$$
y_{i t}=\alpha+\beta_{y} Z_{i t}+\beta_{z} X_{i t}+\varepsilon,
$$

where $y_{i t}$ is the GDP per capital for each country and year, $Z_{i t}-$ fiscal decentralization measure (FDI) for each country and year, $X_{i t}$ - quantitative indicators - is a set of six control variables that were found to be significant in almost all economic growth researches (Nguyen, Anwar 2011; Baskaran, Feld 2013; Cantarero, Gonzalez 2009; Stoilova, Patonov 2012; Gemmel et al. 2013; Yushkov 2015; Lazano, Julio 2015).

The majority of the researches dependent variable use the real GDP per capita (in cross-country researches) or income of real provincial (state) (in particular countries researches).

The basic panel models are defined in Table 3.

Our control variable (X) include: 1) ratio of investment to GDP (INV); 2) economic structure (STRUC); 3) human capital - expenditure for education (HUM); 4) technology (TECH); 5) GDP per working capital (EML); 6) employment (EML). 
Table 3. Evaluation steps of FD effects on economic growth

\begin{tabular}{|c|c|c|}
\hline Stages & Steps of research & Model and method \\
\hline \multicolumn{3}{|c|}{1 Hypothesis: Fiscal decentralization effects economic growth } \\
\hline \multirow[t]{4}{*}{$\begin{array}{l}\text { 1. Evaluate } \\
\text { relationship } \\
\text { between FD and } \\
\text { economic growth }\end{array}$} & $\begin{array}{l}1.1 \text { Evaluate } \\
\text { relationship between } \\
\text { FD and economic } \\
\text { growth in EU-21 }\end{array}$ & $\begin{array}{l}\text { Data normalization: } \\
\left(G D P_{i t}-\min G D P_{E U}\right) /\left(\max G D P_{E U}-\min G D P_{E U}\right)\end{array}$ \\
\hline & & $\begin{array}{l}\text { Fixed effect panel data model, OLS method } \\
B V P_{i t}=\alpha+\mu_{i}+\beta_{1} F D I_{i t}+\beta_{2} L A B_{i t}+\end{array}$ \\
\hline & & $\beta_{3} I N V_{i t}+\beta_{4} H U M_{i t}+\beta_{5} E M L_{i t}+$ \\
\hline & & $\beta_{6} T_{E C H}+\beta_{7} S T R U C_{i t}+\varepsilon_{i t}$ \\
\hline
\end{tabular}

2 Hypothesis: FD has a different effects on the countries' economic growth depending on the level of economic development

\begin{tabular}{|c|c|c|c|}
\hline \multirow[t]{2}{*}{$\begin{array}{l}\text { 2. Evaluate FD } \\
\text { relationship on } \\
\text { economic growth } \\
\text { in different EU-21 } \\
\text { countries groups }\end{array}$} & $\begin{array}{l}2.1 \text { Evaluate FD } \\
\text { relationship on } \\
\text { economic growth in } \\
\text { high level economic } \\
\text { development } \\
\text { countries }\end{array}$ & $\begin{array}{l}\text { Fixed effect panel data model, OLS method: } \\
B V P_{i t}=\alpha+\mu_{i}+\beta_{1} F D I_{i t}+\beta_{2} L A B_{i t}+ \\
\beta_{3} I N V_{i t}+\beta_{4} H U M_{i t}+\beta_{5} E M L_{i t}+ \\
\beta_{6} T E C H_{i t}+\beta_{7} S T R U C_{i t}+\varepsilon_{i t}\end{array}$ & (4) \\
\hline & $\begin{array}{l}\text { 2.2 Evaluate FD } \\
\text { relationship on } \\
\text { economic growth in } \\
\text { low level economic } \\
\text { development } \\
\text { countries }\end{array}$ & $\begin{array}{l}\text { Fixed effect panel data model, OLS method: } \\
B V P_{i t}=\alpha+\mu_{i}+\beta_{1} F D I_{i t}+\beta_{2} L A B_{i t}+ \\
\beta_{3} I N V_{i t}+\beta_{4} H U M_{i t}+\beta_{5} E M L_{i t}+ \\
\beta_{6} T E C H_{i t}+\beta_{7} S T R U C_{i t}+\varepsilon_{i t}\end{array}$ & (5) \\
\hline
\end{tabular}

Source: compiled by author.

Fiscal decentralization index $(Z)$ consists of four different variables (subindixes): 1) revenue decentralization; 2) expenditure decentralization; 3) transfers to subnational government from other government levels; 4) borrow decentralization.

The study employs the equation form used by Lapinskiene et al. (2014, 2015). The purpose of the model was to know whether fiscal decentralization effect on economic growth is the same in high economic development countries and low economic development countries. In the last part was presented research results.

\section{Fiscal decentralization effects on economic growth empirical analysis}

In the first step was calculated index of fiscal decentralization (Slavinskaitè, Ginevičius 2016). Results of calculation are shown in Figure 1 ( $a$ and b) for countries of high economic development level and countries of low economic development level. As seen in Figure 1, fiscal decentralization index ranges from as high as 0.71 in Sweden and less 0.30 in Ireland in high economic development countries. In contrast to the situation in the low economic development countries, where fiscal decentralization index is less 
then 0.5 (see Fig. 1). The fiscal decentralization highest index has Hungary $(0.50)$ and lowest FD index in Lithuania and Bulgaria, only 0.28. Fiscal decentralization index is the lowest among 21 Europe countries in Lithuania and Bulgaria.

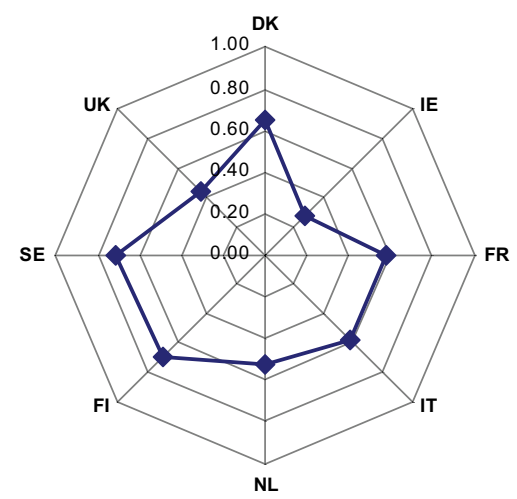

a) HGDP countries

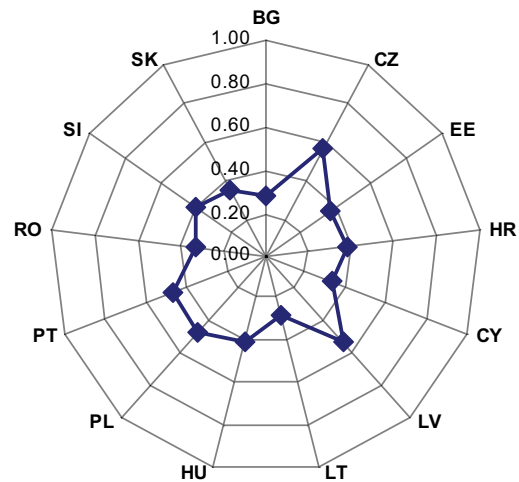

b) LGDP countries

Fig. 1. Fiscal decentralization index in HGDP and LGDP countries Source: compiled by author.

The estimated results in the Table 4 indicate that economic growth is positively associated with fiscal decentralization and economic growth in EU-21 countries. The estimated coefficient of fiscal decentralization is statistically significant and positive at $1 \%$ level. It is interesting to note that this pattern is consistent with the empirical studies of Jin and Zou (2005) and Zhang and Zou (1998). $\mathrm{R}^{2}$ and Adjusted $\mathrm{R}^{2}$ have been calculated by Eviews. R-squared is 0.998 and Adjusted R-squared is 0.9999 . R squared is very high due to its specific estimation for the pooled data series.

Specifically, the P-value of Student's test was used to examine the statistical significance of the effect of the independent variables on the dependent variable. In this economic growth estimation, $\mathrm{P}-$ value was used to determine the significance of FDI $(-1)$, LAB, INV, HUM, EML, TECH, STRUC. When P-value is lower than 0.05, it indicates that this coefficient has a statistically significant explanatory power with the probability of $95 \%$ (it is provided in column "Prob." in Table 4).

The F-statistic was used to test the overall fit of the model or, more specifically, if all of the slope coefficients in the regression model are zero. As shown in the 4 Table, F-statistics of the fixed effect model is 3981.06 , while probability of zero F-statistics is non-existent. DW-statistic is 1.0922. Autocorrelation interval at significant level 5\%: lower -1.697 , upper $1.841 \%$. It is mean, that this model does not have autocorrelation.

Table 5 presented the estimated results indicate that relationship between fiscal decentralization and economic growth is positive in high level economic development countries, but there is not statistically significant linkage between FD and economic growth. $\mathrm{R}$-squared is 0.9958 and Adjusted R-squared is 0.9947 . R squared is very high due to its specific estimation for the pooled data series. 
Table 4. Fiscal decentralization effect on economic growth in ES-21 countries

\begin{tabular}{lcccc}
\hline \multicolumn{1}{c}{ Variable } & Coefficient & Std. error & T-Statistic & Prob. \\
\hline C & -0.08114 & 0.03895 & -2.0835 & $0.0388^{* *}$ \\
\hline FDI(-1) & 0.19026 & 0.04604 & 4.1322 & $0.0001^{* * *}$ \\
\hline LAB & 0.00153 & 0.00025 & 6.0672 & $0.0000^{* * *}$ \\
\hline INV & 0.00386 & 0.00041 & 9.3160 & $0.0000^{* * *}$ \\
\hline HUM & 0.00004 & 0.00000 & 4.2013 & $0.0000^{* * *}$ \\
\hline EML & 0.00101 & 0.00037 & 2.7117 & $0.0073^{* * *}$ \\
\hline TECH & 0.00052 & 0.00009 & 5.5312 & $0.0000^{* * *}$ \\
\hline STRUC & 0.00246 & 0.00072 & 3.4164 & $0.0008^{* * *}$ \\
\hline & & Effect specification & \\
\hline R squared & & 0.9985 & \\
\hline Adjusted R squared & & & 0.9992 & \\
\hline F-statistic & & 3981.06 & \\
\hline DW & & & \\
\hline Prob (F-statistic) & & & \\
\hline
\end{tabular}

Source: compiled by author.

Table 5. Fiscal decentralization effect on economic growth in high level economic development countries

\begin{tabular}{lcccc}
\hline \multicolumn{1}{c}{ Variable } & Coefficient & Std. error & T-Statistic & Prob. \\
\hline C & 0.29669 & 0.08707 & 3.40762 & $0.0012^{* * *}$ \\
\hline FDI(-1) & 0.13183 & 0.08986 & 1.46698 & 0.1479 \\
\hline LAB & 0.00033 & 0.00037 & 0.87110 & 0.3874 \\
\hline INV & 0.00746 & 0.00101 & 7.35915 & $0.0000^{* * *}$ \\
\hline HUM & 0.00111 & 0.00143 & 0.78035 & 0.4384 \\
\hline EML & 0.00567 & 0.00110 & 5.13440 & $0.0000^{* * *}$ \\
\hline TECH & 0.00042 & 0.00014 & 3.03774 & $0.0036^{* * *}$ \\
\hline STRUC & 0.00430 & 0.00118 & 3.63906 & $0.0006^{* * *}$ \\
\hline & & Effect specification & & \\
\hline R squared & & 0.9958 & \\
\hline Adjusted R squared & & & 0.9947 & \\
\hline F-statistic & & 953.84 & \\
\hline DW & & & 0.0000 & \\
\hline Prob (F-statistic) & & & \\
\hline
\end{tabular}


As shown in the 5 Table, F-statistics of the fixed effect model is 953.84, while probability of zero F-statistics is non-existent. DW-statistic is 1.1541. Autocorrelation interval at significant level 5\%: lower -1.428 , upper $1.834 \%$. What it means is, that this model does not have autocorrelation.

The other economic growth variables - investment, employment, technology and economic structure can explain the significant effect on economic growth. The estimated results presented in Table 6 indicate that relationship between fiscal decentralization and economic growth is statistically significant and positive in low level economic development countries.

Table 6. Fiscal decentralization effect on economic growth in low level economic development countries

\begin{tabular}{lcccc}
\hline \multicolumn{1}{c}{ Variable } & Coefficient & Std. error & T-Statistic & Prob. \\
\hline C & -0.17889 & 0.03316 & -5.3951 & $0.0000^{* * *}$ \\
\hline FDI(-1) & 0.10493 & 0.05377 & 1.95139 & $0.0539^{* *}$ \\
\hline LAB & 0.00219 & 0.00027 & 8.20394 & $0.0000^{* * *}$ \\
\hline INV & 0.00296 & 0.00035 & 8.49919 & $0.0000^{* * *}$ \\
\hline HUM & 0.00007 & 0.00001 & 5.40709 & $0.0000^{* * *}$ \\
\hline EML & 0.00065 & 0.00027 & 2.43965 & $0.0165^{* *}$ \\
\hline TECH & 0.00029 & 0.00010 & 2.92714 & $0.0043^{* * *}$ \\
\hline STRUC & 0.00102 & 0.00057 & 1.78203 & 0.0779 \\
\hline & & Effect specification & & \\
\hline R squared & & 0.9946 & \\
\hline Adjusted R squared & & & 0.9935 & \\
\hline F-statistic & & 947.55 & \\
\hline DW & & & \\
\hline Prob (F-statistic) & & & & \\
\hline Source: conpicd & & & \\
\hline
\end{tabular}

Source: compiled by author.

R-squared is 0.9946 and Adjusted R-squared is 0.9935. R squared is very high due to its specific estimation for the pooled data series. As shown in the 6 table, F-statistics of the fixed effect model is 947.55, while probability of zero F-statistics is non-existent. DW-statistic is 1.3026. Autocorrelation interval at significant level 5\%: lower -1.637 , upper 1.832. It is mean, that this model do not have autocorrelation.

This evaluation show that if fiscal decentralization increases $1 \%$, economic growth will increase by $0.10 \%$. The other economic growth variables - labour productivity, investment, human capital, employment, technology and economic structure can explain the significant, positive effect on economic growth. 


\section{Conclusions}

The main objective of the paper has been to provide theory and evidence on the relationship between fiscal decentralization and economic growth in EU countries. The purpose of the paper was to analyse the impact fiscal decentralization on economic growth in unitary European countries for the period 2004-2014. The analysis used data taken from OECD Fiscal decentralization Database, OECD, Word Bank and Eurostat. Fiscal decentralization index was used in the empirical analysis. The empirical test related to fiscal decentralization and economic growth was based on multiple regression model Fixed effect.

Results show that the degree of fiscal decentralization varies widely across country: from 0.26 in Bulgaria and Lithuania to 0.70 in Sweden and Finland. The degree of fiscal decentralization in high level economically developed countries is higher then in low level economically developed countries. These results show that local government in high level economically developed countries (such like Sweden, Denmark and other countries) has a big power to control own revenue and expenditures than in low level economically developed countries (Estonia, Poland and other countries).

Findings of dynamic panel analysis confirm significant and positive impact of fiscal decentralization on economic growth in EU-21 countries. Although the relationship is positive and significant between fiscal decentralization and economic growth in low level economically developed countries, different situation is in high level economically developed countries - relation is no significance.

The article illustrates the current situation with fiscal decentralization in unitary EU countries and its potential link to countries economic growth. Identifying a clear causal relationship between fiscal decentralization and growth and solving the issues of dual causality and endogeneity in the model fall beyond the scope of the article, although it is of substantial interest for the future research of EU fiscal federalism. Actually, there are a lot of factors that can influence economic growth however, because of the limitation of data available only seven variables were used in this research paper.

\section{References}

Abdellatif, L.; Atlam, B.; Aly, H. 2015. Revisiting the relation between decentralization and economic growth in the context of marketization, Eastern Europe Economics 53(4): 255-276. https://doi.org/10.1080/00128775.2015.1065152

Aleksejeva, L. 2016. Country's competitiveness and sustainability: higher education impact, Journal of Security and Sustainability Issues 5(3): 355-363. https://doi.org/10.9770/jssi.2015.5.3(4)

Akai, N.; Sakata, M. 2002. Fiscal decentralisation contributes to economic growth: evidence from state-level cross-section data for the United States, Journal of Urban Economic 52(1): 93-108. https://doi.org/10.1016/S0094-1190(02)00018-9

Akai, N.; Hosoi, N.; Nishimura, Y. 2009. Fiscal decentralization and economic volatility: evidence from state-level cross section data of the USA, Japanese Economic Review 60(2): 223 235. https://doi.org/10.1111/j.1468-5876.2008.00450.x 
Akai, N.; Nishimura, Y.; Sakata, M. 2004. Fiscal decentralization, economic growth and economic volatility - theory and evidence from state-level cross-section data for the United States. Discussion Paper Series 03-F-2.

Asatryan, Z.; Feld, L. 2015. Revisiting the link between growth and federalism: a Bayesian model averaging approach, Journal of Comparative Economics 43(3): 772-781.

https://doi.org/10.1016/j.jce.2014.04.005

Barro, R. 1990. Government spending in a simple model of endogenous growth, Journal of Political Economy 98: 108-125. https://doi.org/10.1086/261726

Baskaran, T.; Feld, L. P. 2013. Fiscal decentralisation and economic growth in OECD countries. Is there a relationship?, Public Finance Review 41(4): 421-445.

https://doi.org/10.1177/1091142112463726

Brennan, G.; Buchanan, J. 1980. The power to tax: analytical foundations of a fiscal constitution. Cambridge: Cambridge University Press.

Buser, W. 2011. The impact of fiscal decentralization on economic performance in high income OECD nation: an institutional approach, Public Choise 149(1): 31-48.

https://doi.org/10.1007/s11127-011-9827-6

Cantarero, D.; Gonzalez, P. P. 2009. Fiscal decentralization and economic growth: evidence from Spanish regions, Public Budgeting \& Finance 29(4): 24-44.

https://doi.org/10.1111/j.1540-5850.2009.00941.x

Chu, J.; Zheng, X. P. 2013. China's fiscal decentralization and regional economic growth, Japanese Economic Review 64(4), 537-550. https://doi.org/10.1111/jere.12013

Davoodi, H.; Zou, H. 1998. Fiscal decentralization and economic growth: a cross-country study, Journal of Urban Economics 43: 244-257. https://doi.org/10.1006/juec.1997.2042

Eller, M. 2004. The determinants of fiscal decentralization and its determinants on economic growth: empirical evidence from a panel of OECD countries: Diploma Thesis.

EUROSTAT. 2016. European Commission database [online], [cited 20 November 2016]. Luxembourg: European Commission. Available from Internet: http://ec.europa.eu/eurostat/data/database

Filippetti, A.; Sacchi, A. 2016. Decentralization and economic growth reconsidered: the role of regional authority, Environment and Planning C: Politics and Space 34(8): 1793-1824.

https://doi.org/10.1177/0263774X16642230

Fuschi, D. L.; Tvaronavičienè, M. 2016. A network based business partnership model for SMEs management, Entrepreneurship and Sustainability Issues 3(3): 282-289.

https://doi.org/10.9770/jesi.2016.3.3(5)

Gemmell, N.; Kneller, R.; Sant, I. 2013. Fiscal decentralization and economic growth: spending versus revenue decentralization, Economic Inquiry 51(4): 1915-1931.

https://doi.org/10.1111/j.1465-7295.2012.00508.x

Genys, D. 2016. Towards sustainable development: tackling relations between energy security and social exclusion, Journal of Security and Sustainability Issues 6(1): 27-36.

https://doi.org/10.9770/jssi.2016.6.1(2)

Hammond, G. W.; Tosun, M. S. 2011. The impact of local decentralization on economic growth: evidence from U.S. counties, Journal of Regional Science 51(1): 47-65.

https://doi.org/10.1111/j.1467-9787.2010.00683.x

Iimi, A. 2005. Decentralization and economic growth revised an empirical note, Journal of Urban Economics 57(3): 449-641. https://doi.org/10.1016/j.jue.2004.12.007

Ignatavičius, R.; Tvaronavičienè, M.; Piccinetti, L. 2015. Sustainable development through technology transfer networks: case of Lithuania, Journal of Security and Sustainability Issues 4(3): 261-267. https://doi.org/10.9770/jssi.2015.4.3(6) 
Jalil, A.; Feridun, M.; Sawhney, B. L. 2014. Growth effect of fiscal decentralization: empirical evidence from China's provinces, Emerging Markets Finance \& Trade 50(4): 176-196. https://doi.org/10.2753/REE1540-496X500411

Jin, J.; Zou, H. 2005. Fiscal decentralization, revenue and expenditure assignments, and growth in China, Journal of Asian Economic 16: 1047-1064. https://doi.org/10.1016/j.asieco.2005.10.006 Lapinskienè, G.; Peleckis, K.; Radavičius, M. 2015. Economic development and greenhouse gas emissions in the European Union countries, Journal of Business Economics and Management 16(6): 1109-1123. https://doi.org/10.3846/16111699.2015.1112830

Lapinskienè, G.; Tvaronavičienè, M.; Vaitkus, P. 2014. The emissions of greenhouse gases and economic growth - the evidence of the presence of the environmental Kuznets curve in the European Union countries, Technological and Economic Development of Economy 20(1): 65-78. https://doi.org/10.3846/20294913.2014.881434

Lazano, I.; Julio, M. J. 2015. Fiscal decentralization and economic growth: evidence from regional-level panel data for Colombia. Borradores de Economia 865I.

Lin, J.; Liu, Z. 2000. Fiscal decentralization and economic growth in China, Economic Development and Cultural Change 49: 1-22. https://doi.org/10.1086/452488

Musgrave, R. A. 1959. The theory of public finance. A study in public economy. New York: McGraw Hill. 628 p.

Nguyen, L.; Anwar, S. 2011. Fiscal decentralization and economic growth in Vietnam, Journal of the Asia Pacafic Economy 16(1): 3-14. https://doi.org/10.1080/13547860.2011.539397

Oates, W. E. 1972. Fiscal federalism. New York: Harcourt Brace Jovanovich.

Oates, W. E. 1993. Fiscal decentralisation and economic development, National Tax Journal 46(2): 237-243.

Oates, W. E. 1999. An essay on fiscal federalism, Journal of Economic Literature 37(3): 11201149. https://doi.org/10.1257/jel.37.3.1120

Organization for economic, Co-operation and Development Database (OECD). 2016. OECD Fiscal Decentralisation Database [online], [cited 07 November 2016]. France: Organization for economic, Co-operation and Development. Available from Internet: http:/www.oecd.org/ctp/ federalism/fiscal-decentralisation-database.htm

Rodríguez-Pose, A.; Ezcurra, R. 2011. Is fiscal decentralisation harmful for economic growth? Evidence from the OECD countries, Journal of Economic Geography 11(4): 619-643.

https://doi.org/10.1093/jeg/lbq025

Rodríguez-Pose, A.; Kroijer, A. 2009. Fiscal decentralization and economic growth in Central and Eastern Europe, Growth and Change 40(3): 387-417.

https://doi.org/10.1111/j.1468-2257.2009.00488.x

Slavinskaitè, N.; Ginevičius, R. 2016. Revenue autonomy of local government: fiscal decentralization aspect in 9th International Scientific Conference "Business and Management 2016", 12-16 May 2016, Vilnius, Lithuania.

Stansel, D. 2005. Local decentralization and local economic growth: a cross-sectional examination of US metropolitan areas, Journal of Urban Economics 57: 55-72.

https://doi.org/10.1016/j.jue.2004.08.002

Stoilova, D.; Patonov, N. 2012. Fiscal decentralization: is it a good choice for the small new member states of the EU?, Scientific Annals of the "Alexandru Ioan Cuza” University of Iasi, Economic Sciences Section 59(1): 125-137.

Szarowska, I. 2014. Fiscal decentralization and economic development in selected European countries, European Financial and Accounting Journal 9(1): 22-40. 
Thiessen, U. 2003. Fiscal decentralisation and economic growth in high income OECD countries, Fiscal Studies 24: 237-74. https://doi.org/10.1111/j.1475-5890.2003.tb00084.x

Thornton, J. 2007. Fiscal decentralisation and economic growth reconsidered, Journal of Urban Economics 61(1): 64-70. https://doi.org/10.1016/j.jue.2006.06.001

Tiebout, Ch. 1956. A pure theory of local expenditures, Journal of Political Economy 64(5): 416-424. https://doi.org/10.1086/257839

Travkina, I.; Tvaronavičienè, M. 2015. Peculiarities of export structure in Lithuania: synthesis and analysis, Entrepreneurship and Sustainability Issues 2(4): 233-247.

Tunčikienè, Ž.; Drejeris, R. 2015. Entrepreneurship ecosystem: methodological approaches to functions' review of public sector institutions, Entrepreneurship and Sustainability Issues 2(3): 118-132. https://doi.org/10.9770/jesi.2014.2.3(1)

Yang, Z. 2016. Tax reform, fiscal decentralization and regional economic growth: new evidence from China, Economic Modelling 59: 520-528. https://doi.org/10.1016/j.econmod.2016.07.020

Yushkov, A. 2015. Fiscal decentralization and regional economic growth: theory, empirics, and the Rusian experience, Rusian Journal of Economics 1: 404-418.

https://doi.org/10.1016/j.ruje.2016.02.004

Zhang, T.; Zou, H. 1998. Fiscal decentralization, public spending, and economic growth in China, Journal of Public Economics 67: 221-240. https://doi.org/10.1016/S0047-2727(97)00057-1

Wahl, M.; Prause, G. 2013. Toward understanding resources, competencies, and capabilities: business model generation approach, Entrepreneurship and Sustainability Issues 1(2): 67-80.

https://doi.org/10.9770/jesi.2013.1.2(1)

World Bank. 2016. World bank database [online], [cited 15 November 2016]. Washington: World Bank. Available from Internet: http://data.worldbank.org/

Neringa SLAVINSKAITE் obtained her PhD in Social Sciences (Economic) at Faculty of Business Management at Vilnius Gediminas Technical University. Her research interests include fiscal decentralization, autonomy of local government and economic growth. 